\title{
Site factors as predictors for Pinus halepensis Mill. productivity in Spanish plantations
}

\author{
Teresa Bueis $^{1,2}$ • Felipe Bravo ${ }^{1,3}$ • Valentín Pando ${ }^{1,4}$ • María-Belén Turrión ${ }^{1,2}$
}

Received: 25 April 2016 / Accepted: 16 December 2016 /Published online: 6 February 2017

(C) INRA and Springer-Verlag France 2017

\begin{abstract}
- Key message This work presents a discriminant model to predict Pinus halepensis forest productivity using parameters related to water availability (Annual Hydric Index, soil porosity and slope) and information about the $\mathrm{N}$ immobilization by soil microorganisms (microbial biomass $\mathbf{N}$ ).

- Context Pinus halepensis is a circum-Mediterranean species that has been widely used for afforestation of poor and degraded soils in water-limited regions. Determining forest and stand productivity is very useful for forest managers as it supports decision making.
\end{abstract}

\section{Handling Editor: Andreas Bolte}

Contributions of the co-authors Teresa BUEIS: designed the experiment, carried out the field and laboratory work, run the data analysis, discussed the results and wrote the paper

Felipe BRAVO: designed the experiment, coordinated the research project and corrected the manuscript

Valentín PANDO: supported the statistical analysis and corrected the manuscript

María-Belén TURRIÓN: designed the experiment, supervised the laboratory analysis and corrected the manuscript

Electronic supplementary material The online version of this article (doi:10.1007/s13595-016-0609-7) contains supplementary material, which is available to authorized users.

María-Belén Turrión

bturrion@agro.uva.es

Teresa Bueis

teresa.bueis@agro.uva.es

Felipe Bravo

fbravo@pvs.uva.es

Valentín Pando

vpando@eio.uva.es
- Aims The aim of this study was to develop a model to predict Pinus halepensis productivity using environmental parameters.

- Methods A set of 57 soil, climatic and physiographic parameters were determined in 32 Pinus halepensis plots, which were categorized into three site index classes. Principal component analysis (PCA) was used to select the 14 environmental variables that accounted for the highest data variability. Discriminant models with three, four and five environmental variables as predictors were studied.

- Results The selected discriminant model included three parameters related to water availability (Annual Hydric Index, soil porosity and slope), which is the main driver of forest productivity in Mediterranean ecosystems, and one nutrientrelated parameter known as microbial biomass $\mathrm{N}$, by which microorganisms inform about $\mathrm{N}$ immobilization. The model correctly classified $62.5 \%$ of the plots.

- Conclusion This model may be a very useful tool for supporting decision making in forestry practices aimed at sustainable stand management.

Keywords Soil-site method · Site index · Environmental factor $\cdot$ Discriminant analysis $\cdot$ Principal component analysis

1 Sustainable Forest Management Research Institute, University of Valladolid and INIA, Avda. Madrid 44, 34004 Palencia, Spain

2 Departamento de Ciencias Agroforestales, E.T.S. Ingenierías Agrarias, Universidad de Valladolid, Palencia, Spain

3 Departamento de Producción Vegetal y Recursos Forestales, E.T.S. Ingenierías Agrarias, Universidad de Valladollid, Palencia, Spain

4 Departamento de Estadística e Investigación Operativa, E.T.S. Ingenierías Agrarias, Universidad de Valladolid, Palencia, Spain 


\section{Introduction}

Pinus halepensis Mill. is a circum-Mediterranean, droughtadapted species that covers broad areas of Spain, France and Italy. As the second most extensive species by area in Spain (outnumbered only by Quercus ilex L. with 2.8 million hectares), it covers two million hectares, of which natural stands account for around 806,000 ha. This species has been widely used for reforestation of degraded soils in arid and semiarid regions of Spain such as Castilla y León, where $P$. halepensis plantations currently cover almost 20,000 ha (DGCN 2002). Broadleaf species such as Q. ilex L. and Quercus faginea Lam. had grown naturally in these areas before they were transformed into croplands during the last century. Soil erosion became a huge problem when the croplands were abandoned, especially in areas with steep slopes. Pinus halepensis was extensively planted to protect and improve soils, and $Q$. ilex and $Q$. faginea are now beginning to grow in these stands. Thus, these plantations have a primarily protective, but also a productive, function. Determining forest productivity can inform decision making in forest management in order to achieve both protective and productive goals for these stands. Useful guidelines for silvicultural practices, such as thinning in plantations on poor and limy soils (Montero et al. 2001), can avoid slowing down forest growth. Similarly, when forest potential productivity information is available prior to plantation, the most suitable species can be selected for afforestation projects (Bravo-Oviedo and Montero 2005). In short, reliable productivity models are necessary for sustainable forest management.

Stand height is the most suitable forest productivity indicator for even-aged stands because of the correlation between height growth and volume growth (Heyer 1841; Skovsgaard and Vanclay 2008). Site index (dominant height at a reference age) has been widely used as a forest productivity indicator because dominant height is less influenced by standard silviculture (Ortega and Montero 1988). Sometimes, site index cannot be determined because dominant height is not available (for example, in stands subjected to thinning from above or high grading or in new afforestations). In these cases, the site index can be estimated by means of its relationship to environmental factors.

Several authors have studied the relationship between forest productivity and environmental parameters, which often include climatic, physiographic and physical/chemical soil parameters (Aertsen et al. 2010; Bravo et al. 2011; SanchezRodriguez et al. 2002). However, parameters related to the soil organic horizon are less frequently considered (Laamrani et al. 2014; Romanya and Vallejo 2004) and soil biochemical parameters - which constitute key soil quality indicators (Bueis et al. 2016b; Muscolo et al. 2014; Schloter et al. 2003; Staddon et al. 1999) — are seldom included (Mahía et al. 2006; Pietrzykowski et al. 2015).

Several studies, some of them focusing on $P$. halepensis to predict climate change impact on forest growth, tend to agree on climate as the main factor driving species growth (Condes and Garcia-Robredo 2012; Gandullo et al. 1972; Girard et al. 2011; Klein et al. 2014; Rathgeber et al. 2005; Río et al. 2014; Sabate et al. 2002). Río et al. (2014) also related the lower $P$. halepensis site index in south-eastern Spain to lower nutrient availability, lower cation exchange capacity, higher $\mathrm{C}$ to $\mathrm{N}$ ratio and lower soil clay content. Most efforts at predicting site productivity from site parameters have concentrated on more productive species such as Pinus radiata D. Don, Pinus pinaster Ait. or Pinus sylvestris L. (Afif-Khouri et al. 2010; Alvarez-Alvarez et al. 2011; Bueis et al. 2016b).

The main aim of this study was to develop a model for predicting the site index of $P$. halepensis plantations in northern Spain using soil (physical, chemical, biochemical and related to the organic horizon), climatic and physiographic parameters. We hypothesise that, according to the available literature, site quality for $P$. halepensis plantations in Castilla y León may be predicted by means of soil and climatic parameters related to water and nutrient availability.

\section{Material and methods}

\subsection{Study area and sampling plots}

This study was developed in 32 plots (Online Resource 1) in man-made $P$. halepensis stands belonging to the Spanish National Forest Inventory (DGCN 2002) and located in the centre of the region of Castilla y León. Predominant understory species included $Q$. ilex, $Q$. faginea, Genista scorpius (L.) D.C., Dorycnium pentaphyllum Scop., Staehelina dubia L., Lithodora fruticosa L. and Salvia lavandulifolia Vahl. Stand age ranged from 45 to 61 years, and the slope in the plots ranged from 0 to $55 \%$. The calcareous soils originated from carbonate-rich parent materials and can be classified as Calcixerepts within the Inceptisol order (Llorente and Turrion 2010). Soil reaction was alkaline with $\mathrm{pH}$ ranging from 8 to 8.9. Mean annual temperature of the area is $11.7^{\circ} \mathrm{C}$, mean annual precipitation is $456 \mathrm{~mm}$, mean temperature of the warmest month is $20.9^{\circ} \mathrm{C}$ and mean temperature of the coldest month is $3.8^{\circ} \mathrm{C}$. The Lang, Martonne and Annual Hydric Indexes all classify this area as arid/sub-humid. Table 1 shows the main silvicultural characteristics of the plots studied.

Stand age for every plot was established as the difference between the year of plantation and the year when the Third National Forest Inventory was carried out. Dominant height $\left(H_{0}\right)$ was determined for each plot based on data from the 
Table 1 Stand characteristics of Pinus halepensis Mill. plots $(n=32)$ used to develop a discriminant model for predicting the site index in calcareous plantations in northern Spain

\begin{tabular}{lllll}
\hline Parameters & Mean & S.D. & Minimum & Maximum \\
\hline Stand age (years) & 53.8 & 4.3 & 45.0 & 61.0 \\
Stocking (trees ha $^{-1}$ ) & 859.5 & 428.7 & 293.6 & 1711.8 \\
Dominant height (m) & 8.6 & 1.7 & 5.5 & 12.0 \\
Mean height (m) & 7.1 & 1.6 & 4.6 & 11.2 \\
Quadratic mean diameter (cm) & 16.3 & 3.6 & 10.3 & 26.2 \\
Basal area $\left(\mathrm{m}^{2} \mathrm{ha}^{-1}\right.$ ) & 15.8 & 5.5 & 9.1 & 32.0 \\
Site index (m height at 80 years age) & 10.9 & 2.2 & 6.8 & 15.0 \\
\hline
\end{tabular}

S.D. standard deviation
Third National Forest Inventory (DGCN 2002), following the Assmann (1970) criterion. Site index (SI) was estimated for each plot using the equation developed by Montero et al. (2001):

$H_{0}=a \cdot\left(1-e^{-0.203954 \cdot t}\right)^{1 / 1.046295}$

where $H_{0}$ is the dominant height in meters and $t$ is the age in years. The value of $a$ was determined for every plot from the previous equation and the current $H_{0}$ and $t$ values. To determine site index for each plot (dominant height at the reference age of 80 years), the value of $a$ for each plot and the reference age $(t=80$ years) were introduced into the equation and the resulting value of $H_{0}$ was the site index. Three quality classes were established based on the site index value for each plot: low (site index ranging between 6.5 and 9.5), medium (site index between 9.5 and 12.5) and high (site index between 12.5 and 15.5). Accordingly, 8 plots were classified into the lowest quality class, 9 into the highest quality class and 15 into the medium quality class.

\subsection{Sampling}

Soil sampling included the forest floor or organic horizon and $10 \mathrm{~cm}$ of mineral topsoil, based on the method of Jokela et al. (1988). Bravo et al. (2011) and Bueis et al. (2016b) also adopted this method, as environmental changes are more strongly reflected in this layer. Each plot had four sampling points located $5 \mathrm{~m}$ from the centre of the plot in N, S, E and W directions. At each point, one disturbed and one undisturbed soil mineral sample were taken. Undisturbed samples were collected in a steel cylinder ( $5 \mathrm{~cm}$ diameter and $5 \mathrm{~cm}$ height) to maintain their original structure. The four disturbed samples from each plot were grouped together to obtain a composite mineral soil sample per plot.

The organic horizon was divided into two fractions: almost undecomposed litter fraction (L) and fragmented fraction plus humified fraction $(\mathrm{FH})$. This horizon was sampled in $20 \times 20$ $\mathrm{cm}$ quadrants and mixed to get a composite sample of each fraction per plot. The total organic horizon thickness (OHT) was measured in the field.

\subsection{Physical, chemical and biochemical soil analysis}

Disturbed mineral soil samples were air-dried at $105^{\circ} \mathrm{C}$ and sieved with a $2-\mathrm{mm}$ screen before analysis. All analyses were done in duplicate. Bulk density and field capacity were determined with the samples of undisturbed soil.

Physical parameters included percentage of coarse particles (>2 mm); particle distribution by pipette method (MAPA 1993) and subsequent determination of clay content, sand and silt following the International criteria (ISSS) and silt and sand following the USDA criteria; porosity by determining bulk and real density; and available water as the difference between water content at field capacity and the permanent wilting point, which were determined using Eijkelkamp pFEquipment.

Chemical parameters included $\mathrm{pH}$ using a 1:2.5 (soil/water) suspension (MAPA 1993); easily oxidizable carbon (EOC) through the Walkley and Black (1934) method; cation exchange capacity (CEC); exchangeable cations ( $\mathrm{Ca}, \mathrm{Mg}, \mathrm{K}$ and $\mathrm{Na}$ ) by means of extraction with $1 \mathrm{~N}$ ammonium acetate ( $\mathrm{pH}=7$ ) (Schollenberger and Simon 1945) and subsequent determination of cations in the extract using an atomic absorption/emission spectrometer; Fe, Al, Zn and Mn contents following the DTPA-TEA method (Lindsay and Norvell 1978); available P (AP), which was extracted using anion exchange membranes (Turrión et al. 1997) and determination of $\mathrm{P}$ in the extracts using colorimetry (Murphy and Riley 1962); gypsum content (Richards 1954); total calcium carbonates following the methodology of Bundy and Bremner (1972); total N (TN) through dry combustion using a LECO CHN 2000 elemental analyser; total organic C (TOC) by subtraction of $\mathrm{C}$ content in carbonates from the total $\mathrm{C}$ content in soil, measured with a LECO CHN 2000 analyser and reactive calcium carbonates following the Bashour and Sayegh (2007) modification of the Drouineau (1942) method.

Biochemical parameters included mineralizable $\mathrm{C}$ (Isermeyer 1952); microbial biomass C, N and P following 
the fumigation-extraction method (Vance et al. 1987) and using a Skalar TOC autoanalyser to determine $\mathrm{C}$ and $\mathrm{N}$ content in extracts and colorimetry to determine $\mathrm{P}$ content (Murphy and Riley 1962). The relationships microbial biomass $\mathrm{C} /$ microbial biomass $\mathrm{N}$, microbial biomass $\mathrm{C} / \mathrm{TOC}$, mineralizable $\mathrm{C} / \mathrm{TOC}$ and the microbial metabolic quotient $\left(\mathrm{qCO}_{2}=\right.$ mineralizable $\mathrm{C} /$ microbial biomass $\left.\mathrm{C}\right)$ were calculated.

Organic horizon samples were dried at $60{ }^{\circ} \mathrm{C}$ and weighed to determine the amount of biomass per hectare for $\mathrm{L}\left(\mathrm{O}_{\mathrm{L}}\right)$ and $\mathrm{FH}\left(\mathrm{O}_{\mathrm{FH}}\right)$ fractions. A representative portion was ground up and analysed with a LECO-CHN 2000 element analyser to determine total $\mathrm{C}$ and total $\mathrm{N}$ concentrations of $\mathrm{L}$ and $\mathrm{FH}$ fractions, as well as the $(\mathrm{TC} / \mathrm{TN})_{\mathrm{L}}$ and $(\mathrm{TC} / \mathrm{TN})_{\mathrm{FH}}$ ratios.

\subsection{Climatic and physiographic data}

Precipitation and temperature data were obtained from the Digital Climatic Atlas for the Iberian Peninsula (Ninyerola et al. 2005), and the climatic parameters calculated were mean seasonal precipitation (PW: winter precipitation; PSP: spring precipitation; PSU: summer precipitation; PA: autumn precipitation), annual total precipitation (TP), mean annual temperature (MAT), mean temperature of the coldest and warmest month (MTCM and MTWM, respectively), mean minimum temperature in the coldest month (MMCM), mean maximum temperature in the warmest month (MMWM) and potential evapotranspiration (PET) following the Thornthwaite (1949) method; actual evapotranspiration, deficit and surplus were calculated based on climatic data (temperature and precipitation) by computing the Monthly Water Balance as described by Thornthwaite and Mather (1955); and Martonne Index (De-Martonne 1926), Lang Index (Lang 1915) and, finally, Annual Hydric Index were calculated through the following expressions as described by Thornthwaite (1949):

Annual Hydric Index $=H-0.6 A H=\frac{\text { Surplus }}{\text { PET }} A=\frac{\text { Deficit }}{\text { PET }}$

Physiographic parameters included elevation and latitude, as recorded in the National Forest Inventory. Slope was measured in the field with a clinometer.

\subsection{Statistical analysis}

First, a principal component analysis (PCA) was applied to each group of variables (physical, chemical and biochemical soil, organic horizon, climatic, physiographic) to reduce dimensionality and select the non-correlated variables that accounted for most of the data variability. The studied variables were standardized before the PCA. This analysis was applied to each group of variables first because it is widely thought that correlations appear mainly between variables belonging to the same group. We selected the principal components that presented an eigenvalue higher than 0.7 and accounted for at least $70 \%$ of the overall data variability. The variable with the highest absolute value coefficient (factor loadings) was chosen to represent each principal component, as proposed by Jolliffe (1973).

The Shapiro-Wilk test was applied to test normality in the selected variables. Those showing lack of normality were transformed using the $\log (\mathrm{X}), \exp (\mathrm{X}), 1 / \mathrm{X}, \mathrm{X}^{2}$ and $\sqrt{\mathrm{X}}$ functions. Transformed variables showing lack of normality were replaced by the variable with the next highest absolute value coefficient in the PCA. The variables selected through PCA were tested for correlation using Pearson's correlation coefficient, to avoid including strongly correlated variables in the discriminant analysis. Finally, a discriminant analysis was carried out to develop a discriminant model for predicting the site index from the variables selected through PCA. Discriminant analysis classifies new cases into established groups according to their properties; discriminant functions have the following general structure:

$Y=\beta_{0}+\sum_{j=1}^{p} \beta_{j} \cdot X_{j}$

where $Y$ is the score obtained for each group, $\beta_{0}, \beta_{1}, \ldots \beta_{p}$ are the coefficients obtained and $X_{j}$ is the value of the $p$ variable selected as the predictor to represent soil, physiographic and climatic factors (Hair et al. 1999). New observations are assigned to the group with the highest score. This classification technique has been used in similar studies (Bravo-Oviedo and Montero 2005; Bravo et al. 2011; Bueis et al. 2016b; Harding et al. 1985). In the discriminant analysis, equal prior probabilities of belonging to a group were considered for the three groups. Resubstitution was used to evaluate the discriminant models. The whole dataset was used to define and evaluate the model so the estimation of the rates of correct resubstitution presents an optimistic bias. Models including combinations of three, four and five variables coherent with biological processes and dynamics were tested. No model included two variables belonging to the same group. Then, the three, four or five variables included on each model belonged to different groups of variables (soil physical, chemical and biochemical, related to the organic horizon, climatic and physiographic variables). The model presenting the highest correct resubstitution rate (percentage of observations correctly classified into their actual class) with the least number of predictor variables was selected. Statistical analyses were performed with Statgraphics Centurion XVI software for Windows (Statgraphics 2014). 


\section{Results}

Edaphic, climatic and physiographic characteristics of the plots studied are summarized in Online Resources 2, 3 and 4, respectively (Bueis et al. 2016a).

The four principal components selected from the PCA of soil physical properties accounted for $93.8 \%$ of the data variability (Table 2). The variables selected for those four principal components were silt (ISSS), coarse particles, porosity and clay. From the PCA of soil chemical properties, seven principal components (accounting for $87.5 \%$ of data variability) were selected and EOC, carbonates, $\mathrm{Zn}$, reactive carbonates, TOC/TN, Fe and gypsum were chosen to represent them. The PCA of soil biochemical properties informed the selection of four principal components that represented $97.8 \%$ of data variability; the biochemical variables selected to represent them were microbial biomass $\mathrm{N}, \mathrm{qCO}_{2}$, mineralizable $\mathrm{C}$ and microbial biomass $\mathrm{P}$. The two principal components selected from the organic horizon PCA accounted for $74.9 \%$ of data variability, and the variables chosen were $\mathrm{O}_{\mathrm{FH}}$ and $(\mathrm{TC} / \mathrm{TN})_{\mathrm{L}}$. Four principal components from the PCA of climatic parameters accounted for $93.6 \%$ variability and correspond to the Martonne index, MTWM, MMWM and PSU. Latitude and slope were the variables selected for the two principal components from the PCA of physiographic parameters, which accounted for $86 \%$ of data variability. In summary, 23 variables were selected from the PCAs of groups of variables, including 17 edaphic variables (silt, coarse particles, porosity, clay, EOC, carbonates, $\mathrm{Zn}$, reactive carbonates, TOC/TN, Fe, gypsum, microbial biomass $\mathrm{N}, \mathrm{qCO}_{2}$, mineralizable $\mathrm{C}$, microbial biomass $\left.\mathrm{P}, \mathrm{O}_{\mathrm{FH}},(\mathrm{TC} / \mathrm{TN})_{\mathrm{L}}\right), 4$ climatic variables (Martonne index, MTWM, MMWM, PSU) and 2 physiographic variables (latitude and slope). Eight principal components (accounting for $86.9 \%$ of the variability) were selected from the PCA of the 17 edaphic variables (physical, chemical, biochemical and related to the organic horizon), and the
Table 2 Principal component analysis summary for each group of variables and variable chosen from each principal component

\begin{tabular}{|c|c|c|c|c|}
\hline $\begin{array}{l}\text { Group of } \\
\text { variables }\end{array}$ & $\begin{array}{l}\text { Component } \\
\text { number }\end{array}$ & $\begin{array}{l}\text { Principal component } \\
\text { accumulated } \\
\text { variance percentage }\end{array}$ & Selected variable ${ }^{a}$ & $\begin{array}{l}\text { Factor loadings } \\
\text { of the variable } \\
\text { selected }\end{array}$ \\
\hline \multirow[t]{4}{*}{ Soil physical } & 1 & 43.7 & Silt (ISSS) & -0.4877 \\
\hline & 2 & 74.1 & Coarse particles & -0.5361 \\
\hline & 3 & 85.6 & Porosity & -0.7457 \\
\hline & 4 & 93.8 & Clay & 0.6813 \\
\hline \multirow[t]{7}{*}{ Soil chemical } & 1 & 28.9 & EOC & 0.4049 \\
\hline & 2 & 48.0 & Carbonates & -0.4140 \\
\hline & 3 & 60.2 & $\mathrm{Zn}$ & -0.6433 \\
\hline & 4 & 69.7 & Reactive Carbonates & 0.5077 \\
\hline & 5 & 76.5 & $\mathrm{TOC} / \mathrm{TN}$ & -0.7105 \\
\hline & 6 & 82.2 & $\mathrm{Fe}$ & 0.4876 \\
\hline & 7 & 87.5 & Gypsum & 0.5808 \\
\hline \multirow[t]{4}{*}{ Soil biochemical } & 1 & 48.1 & Microbial biomass $\mathrm{N}$ & 0.4880 \\
\hline & 2 & 72.2 & $\mathrm{qCO}_{2}$ & -0.6214 \\
\hline & 3 & 87.4 & Mineralizable C & 0.5600 \\
\hline & 4 & 97.8 & Microbial biomass $\mathrm{P}$ & 0.8634 \\
\hline \multirow[t]{2}{*}{ Organic horizon } & 1 & 54.2 & $\mathrm{O}_{\mathrm{FH}}$ & 0.5416 \\
\hline & 2 & 74.9 & $(\mathrm{TC} / \mathrm{TN})_{\mathrm{L}}$ & 0.8376 \\
\hline \multirow[t]{4}{*}{ Climatic } & 1 & 56.7 & Martonne & -0.3180 \\
\hline & 2 & 78.9 & MTWM & 0.4239 \\
\hline & 3 & 88.6 & MMWM & -0.4889 \\
\hline & 4 & 93.6 & PSU & 0.6913 \\
\hline \multirow[t]{2}{*}{ Physiographic } & 1 & 51.9 & Latitude & 0.7119 \\
\hline & 2 & 86.0 & Slope & 0.9694 \\
\hline
\end{tabular}

${ }^{\text {a }}$ Silt ISSS (\%); coarse particles (\%); porosity (\%); clay content (\%); EOC, easily oxidizable C (\%); carbonates $\left(\mathrm{mg} \mathrm{kg}^{-1}\right)$; reactive carbonates ( $\left.\mathrm{mg} \mathrm{kg}^{-1}\right)$; TOC/TN, total organic C/total $\mathrm{N}$ ratio; gypsum $\left(\mathrm{mg} \mathrm{kg}^{-1}\right)$; microbial biomass $\mathrm{N}\left(\mathrm{mg} \mathrm{kg}^{-1}\right)$; $\mathrm{qCO}_{2}$, microbial metabolic quotient $\left(\mathrm{g}\right.$ week $\left.{ }^{-1} \mathrm{~g}^{-1}\right)$; mineralizable $\mathrm{C}\left(\mathrm{g} \mathrm{week}^{-1} \mathrm{~kg}^{-1}\right)$; microbial biomass $\mathrm{P}\left(\mathrm{mg} \mathrm{kg}^{-1}\right) ; \mathrm{O}_{\mathrm{FH}}$, biomass of fragmented plus humified fraction in organic horizon $\left(\mathrm{t} \mathrm{ha}^{-1}\right)$; $(\mathrm{TC} / \mathrm{TN})_{\mathrm{L}}$, total $\mathrm{C} /$ total $\mathrm{N}$ in litter fraction of organic horizon; Martonne, Martonne Index; MTWM, mean temperature of the warmest month $\left({ }^{\circ} \mathrm{C}\right)$; MMWM, mean value of maxima temperature in the warmest month $\left({ }^{\circ} \mathrm{C}\right)$; PSU, summer precipitation $(\mathrm{mm})$; latitude $\left({ }^{\circ}\right)$; slope $(\%)$ 
variables chosen to represent those principal components were microbial biomass $\mathrm{N}$, silt, $\mathrm{qCO}_{2}$, gypsum, $\mathrm{Zn}$, porosity, microbial biomass $\mathrm{P}$ and clay (Table 3 ).

The normality hypothesis was rejected (5\% significance level) for the Zn, Martonne index and MTWM variables. No transformation of these variables presented a normal distribution, so they were replaced by the variable with the next highest absolute value coefficient in the PCA: TOC/TN, Annual Hydric Index and PET, respectively. Both TOC/TN and PET followed a normal distribution, but Annual Hydric Index was transformed into Annual Hydric Index ${ }^{2}$. The final 14 variables selected for the discriminant analysis were silt, clay, porosity, gypsum, TOC/TN, microbial biomass $\mathrm{N}, \mathrm{qCO}_{2}$, microbial biomass P, Annual Hydric Index ${ }^{2}$, PET, MMWM, PSU, latitude and slope. Correlations between selected variables were studied (Table 4), and strong correlations were found between MMWM and PET and latitude, so these pairs of variables were not included together in the discriminant analysis.

Discriminant models including three, four and five variables as predictors were studied. More than a hundred biologically consistent combinations of three, four and five variables belonging to different groups (soil physical, chemical and biochemical variables, along with climatic and physiographic variables) were tested. The resubstitution error rates of the discriminant models studied ranged from 37.50 to $59.37 \%$. As a general rule, models with three predictor variables have a higher resubstitution error than those using four or five variables as predictors. Models that included a soil physical variable (especially clay and porosity), a soil nutrient-related variable (especially chemical or biochemical), a climatic variable (especially Annual Hydric Index ${ }^{2}$ ) and a physiographic variable (especially slope) presented the best correct classification rates. Besides, all models with a correct classification rate higher than $60 \%$ included a biochemical parameter.

The model selected to predict the site index for $P$. halepensis plantations in northern Spain had four variables - porosity, microbial biomass N, Annual Hydric Index ${ }^{2}$ and slope - and presented a correct classification rate of $62.50 \%$. Extreme quality classes (highest and lowest) had a very high correct classification rate (75.00 and $77.78 \%$, respectively). No plot belonging to the highest quality class was misassigned to the lowest quality class, and only $12.5 \%$ of plots belonging to the lowest quality class were misassigned to the highest quality class (Table 5). Table 6 presents the parameters of the discriminant model selected to predict site quality in $P$. halepensis plantations in northern Spain.

\section{Discussion}

The model selected to predict the site index for P. halepensis plantations in northern Spain presented a correct classification rate of $62.50 \%$ and included porosity, microbial biomass $\mathrm{N}$, Annual Hydric Index and slope as the four predictor variables.

Climate is the main driver of Mediterranean forest growth in general and $P$. halepensis growth in particular (del Castillo et al. 2015; Gandullo et al. 1972; Olarieta et al. 2000; Rathgeber et al. 2005; Río et al. 2014). The correlation between precipitation and $P$. halepensis growth is usually significant and positive while the correlation between growth and temperature is significant and negative, because higher temperature provokes higher evapotranspiration and reduces water reserves (Condes and Garcia-Robredo 2012). The discriminant model developed includes Annual Hydric Index as a predictor, combining information about temperature and humidity. The area studied presents an arid climate, so the Annual Hydric Index always had a negative value. Because this variable was not normally distributed, it was transformed into Annual Hydric Index ${ }^{2}$ (a positive value) for inclusion in the discriminant analysis. Thus, the higher the Annual Hydric Index ${ }^{2}$, the drier the climate and the lower the predicted site quality (Table 6).
Table 3 Principal component analysis summary for the 17 edaphic variables selected

\begin{tabular}{lcccc}
\hline $\begin{array}{l}\text { Group of } \\
\text { variables }\end{array}$ & $\begin{array}{l}\text { Component } \\
\text { number }\end{array}$ & $\begin{array}{l}\text { Accumulated } \\
\text { variance percentage }\end{array}$ & Factor loadings & Selected variable $^{\mathrm{a}}$ \\
\hline Soil variables & 1 & 24.2 & 0.4478 & Microbial biomass N \\
& 2 & 41.2 & -0.4729 & Silt (ISSS) \\
3 & 53.2 & -0.5095 & $\mathrm{qCO}_{2}$ \\
4 & 62.1 & -0.4670 & Gypsum \\
5 & 70.0 & 0.5002 & Zn \\
6 & 77.0 & -0.3469 & Porosity \\
7 & 82.7 & -0.5951 & Microbial biomass P \\
8 & 86.9 & 0.5245 & Clay \\
\hline
\end{tabular}

${ }^{\mathrm{a}}$ Microbial biomass N (mg kg $\left.{ }^{-1}\right)$; silt, ISSS (\%); $\mathrm{qCO}_{2}$, microbial metabolic quotient (g week $\left.{ }^{-1} \mathrm{~g}^{-1}\right)$; gypsum $\left(\mathrm{mg} \mathrm{kg}^{-1}\right)$; porosity $(\%)$; microbial biomass $\mathrm{P}\left(\mathrm{mg} \mathrm{kg}^{-1}\right)$; clay content $(\%)$ 
Table 4 Pearson's correlation coefficients among the variables selected for use in the discriminant analysis ${ }^{\mathrm{a}}$

\begin{tabular}{|c|c|c|c|c|c|c|c|c|c|c|c|c|c|}
\hline & Clay & Porosity & Gypsum & $\begin{array}{l}\text { TOC/ } \\
\text { TN }\end{array}$ & $\begin{array}{l}\text { Microbial } \\
\text { biomass } \\
\mathrm{N}\end{array}$ & $\mathrm{qCO}_{2}$ & $\begin{array}{l}\text { Microbial } \\
\text { biomass P }\end{array}$ & $\begin{array}{l}\text { Annual } \\
\text { Hydric } \\
\text { Index }^{2}\end{array}$ & PET & MMWM & PSU & Latitude & Slope \\
\hline Silt (ISSS) & -0.541 & 0.143 & 0.315 & -0.117 & 0.149 & -0.221 & 0.084 & -0.029 & 0.054 & 0.233 & -0.237 & -0.245 & 0.302 \\
\hline Clay & & 0.082 & -0.113 & -0.279 & -0.323 & -0.085 & -0.276 & 0.296 & 0.166 & -0.095 & -0.119 & 0.075 & -0.257 \\
\hline Porosity & & & -0.008 & -0.029 & 0.371 & -0.340 & 0.175 & 0.067 & 0.248 & 0.294 & -0.212 & -0.238 & 0.275 \\
\hline Gypsum & & & & 0.014 & 0.476 & -0.064 & 0.003 & -0.037 & -0.131 & -0.281 & 0.262 & 0.453 & 0.231 \\
\hline $\mathrm{TOC} / \mathrm{TN}$ & & & & & 0.258 & 0.203 & 0.227 & -0.412 & -0.102 & 0.134 & 0.326 & 0.119 & 0.250 \\
\hline $\begin{array}{l}\text { Microbial biomass } \\
\mathrm{N}\end{array}$ & & & & & & -0.268 & 0.354 & -0.482 & -0.286 & -0.148 & 0.395 & 0.182 & 0.430 \\
\hline $\mathrm{qCO}_{2}$ & & & & & & & -0.232 & -0.024 & -0.146 & -0.097 & -0.038 & 0.043 & 0.092 \\
\hline $\begin{array}{l}\text { Microbial biomass } \\
\quad \mathrm{P}\end{array}$ & & & & & & & & -0.084 & 0.167 & 0.186 & -0.023 & 0.030 & 0.203 \\
\hline $\begin{array}{l}\text { Annual Hydric } \\
\text { Index }^{2}\end{array}$ & & & & & & & & & 0.520 & 0.032 & -0.531 & 0.235 & -0.187 \\
\hline PET & & & & & & & & & & 0.724 & -0.193 & -0.275 & 0.037 \\
\hline MMWM & & & & & & & & & & & -0.111 & -0.668 & 0.229 \\
\hline PSU & & & & & & & & & & & & 0.348 & 0.111 \\
\hline Latitude & & & & & & & & & & & & & -0.139 \\
\hline
\end{tabular}

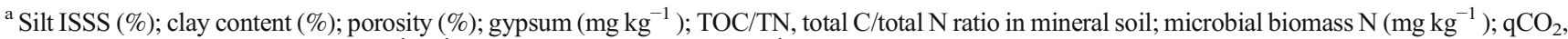
microbial metabolic quotient ( $\left.\mathrm{g} \mathrm{week}^{-1} \mathrm{~g}^{-1}\right)$; microbial biomass $\mathrm{P}\left(\mathrm{mg} \mathrm{kg}^{-1}\right)$; PET, potential evapotranspiration (mm); MMWM, mean value of maxima temperature in the warmest month $\left({ }^{\circ} \mathrm{C}\right)$; PSU, summer precipitation $(\mathrm{mm})$; latitude $\left({ }^{\circ}\right)$; slope $(\%)$

Water availability does not entirely depend on supply through precipitation and loss through evapotranspiration. Soil physical parameters such as particle size distribution or porosity determine the amount of water that percolates down into the soil profile during precipitations as well as the water retention capacity of the soil. Río et al. (2014) found that higher $P$. halepensis site indexes presented soils with clay or loamy clay textures while stands with lower site indexes had lower amounts of clay and were more sensitive to climate. Rathgeber et al. (2005) developed a model that included information about soil water capacity, in addition to precipitation and temperature, to simulate radial $P$. halepensis growth in France. The model selected to predict the $P$. halepensis site index in northern Spain includes porosity, a parameter that can be determined easily, that integrates information about water and the soil aeration regime. In calcareous soils, physical limitations are likely to be compounded by the fine texture and cementing action of calcareous materials. Kishchuk (2000) indicated that calcareous soils may physically affect root penetration, water infiltration and gas exchange in ways similar to compacted soils, with fewer physical limitations as soil porosity increased. Higher porosity in the area studied would thus predict higher P. halepensis site quality, as porosity makes it possible for water to penetrate the soil, reach the rhizosphere and aerate the roots properly.

Physiographic parameters such as slope are often related to forest growth in $P$. halepensis stands all over the Mediterranean region (Al Omary 2011; Condes and Garcia-
Robredo 2012). Slope increases water runoff by diminishing the water percolation into the soil profile and is also related to higher nutrient loss and soil erosion. Eroded materials from steep slopes accumulate in areas with less slope, creating greater depth to carbonates in those areas. Kishchuk (2000) stated that the deeper carbonates in soil correspond to greater forest growth. In other words, as the slope of the plot increased, predicted site quality decreased for $P$. halepensis plantations in northern Spain, which is in accordance with the findings by Al Omary (2011) in P. halepensis plantations in Jordan.

Several studies found that $P$. halepensis growth (which is associated with the site index defined as dominant height at a reference age) is mainly driven by water availability in stands within the natural distribution area of the species in Spain (Condes and Garcia-Robredo 2012; del Castillo et al. 2015; Gandullo et al. 1972; Río et al. 2014). The same trend was found by Olarieta et al. (2000) in P. halepensis plantations in

Table 5 Correct classification resubstitution rates of the model selected to predict site quality in Pinus halepensis plantations in northern Spain

\begin{tabular}{cccc}
\hline Actual quality class (\%) & \multicolumn{3}{l}{ Predicted quality class (\%) } \\
\cline { 2 - 4 } & Lowest & Medium & Highest \\
\hline Lowest & $75.00 \%$ & $12.50 \%$ & $12.50 \%$ \\
Medium & $20.00 \%$ & $46.67 \%$ & $33.33 \%$ \\
Highest & $0.00 \%$ & $22.22 \%$ & $77.78 \%$ \\
\hline
\end{tabular}


Table 6 Discriminant functions coefficients for predicting site quality in Pinus halepensis plantations in northern Spain ${ }^{\mathrm{a}}$

\begin{tabular}{|c|c|c|c|}
\hline & Lowest quality class & Medium quality class & Highest quality class \\
\hline Porosity & 0.898422 & 1.04481 & 1.0651 \\
\hline Microbial biomass $\mathrm{N}$ & 0.268951 & 0.163837 & 0.124966 \\
\hline Annual Hydric Index ${ }^{2}$ & 0.0502579 & 0.0359449 & 0.0292166 \\
\hline Slope & 0.038075 & 0.0370905 & -0.00344083 \\
\hline CONSTANT & -36.9303 & -34.9499 & -31.5711 \\
\hline
\end{tabular}

${ }^{\text {a }}$ Porosity (\%); microbial biomass $\mathrm{N}\left(\mathrm{mg} \mathrm{kg}^{-1}\right)$; slope (\%) northeast Spain. Therefore, water availability seems to be the most limiting factor for the species productivity in Spain, regardless of being within or outside the natural distribution of the species. Moreover, similar results were achieved by Rathgeber et al. (2005) in P. halepensis stands in France, Klein et al. (2014) and Maseyk et al. (2011) in Israel and Toromani et al. (2015) in Albania, so this conclusion may be generalizable to the entire Mediterranean area.

Usually, water availability is included in related studies by means of climatic parameters (Condes and GarciaRobredo 2012; del Castillo et al. 2015; Pasho et al. 2011). However, the amount of water that is actually available for plant roots is determined not only by the contribution of water from precipitations but also by the site factors allowing the water to percolate down the soil profile (Gandullo et al. 1972) and the water retention capacity of soils (Olarieta et al. 2000; Rathgeber et al. 2005) as reflected in the present study.

The model developed to predict $P$. halepensis productivity also included microbial biomass $\mathrm{N}$ as a predictor. Higher microbial biomass $\mathrm{N}$ resulted in lower site productivity in the area studied. Higher values for biochemical properties in soils are generally related to higher forest productivity (Bueis et al. 2016b; Foote et al. 2015; Mahía et al. 2006), as the microorganisms responsible for soil nutrient turnover and availability participate in mineralization processes. However, in some ecosystems, an opposite trend has been observed: microorganisms may actually immobilize $\mathrm{N}$ in soils with very low $\mathrm{N}$ availability or litter input with a very high $\mathrm{C} / \mathrm{N}$ ratio (Recous et al. 1995; Song et al. 2007). Microorganisms can uptake N very quickly because of their high surface-area ratio, which prevents nutrient loss from leaching but creates an $\mathrm{N}$ deficit for the plants (Kuzyakov and Xu 2013). This in turn diminishes stand productivity as $\mathrm{N}$ limits productivity in forest ecosystems.

Models with a correct classification rate higher than $60 \%$ included a biochemical parameter, indicating that biochemical parameters are determining factors in the $P$. halepensis site index. However, laboratory soil analyses do not usually include biochemical analyses, and not all laboratories are equipped for them. When the microbial biomass $\mathrm{N}$ biochemical parameter was removed from the model developed here, the error rate increased by $6.25 \%$. Nevertheless, this reduced model could be an interesting alternative when biochemical soil analyses are not available.

\section{Conclusions}

A discriminant model using environmental parameters related to water and nutrient availability was developed to determine the $P$. halepensis site index for plantations in northern Spain. The model included four parameters, Annual Hydric Index, soil porosity, slope and microbial biomass $\mathrm{N}$. Three of those parameters reflect the water regime of the soil: Annual Hydric Index (which combines temperature and precipitation information), soil porosity (responsible for water penetration in soil and retention in the rhizosphere) and slope (responsible for water runoff on the soil surface). Soil porosity adds information about the aeration regime of the soil, and slope is related to nutrient and soil losses through erosion. The fourth parameter, microbial biomass $\mathrm{N}$, reflects the $\mathrm{N}$ deficit due to microbial immobilization, which is a common reality in $\mathrm{N}$-limited ecosystems. The model developed here presented a correct classification rate of $62.5 \%$ overall, with a high rate of plots correctly classified into the extreme high $(77.8 \%)$ or low $(75.0 \%)$ quality classes. This very interesting fact can inform the focus of forestry practices in P. halepensis plantations in Castilla y León and the choice of optimal species for new afforestation programmes for successful and sustainable stand management in the studied area. Further studies would be necessary to test the validity of this model on independent samples and also to determine whether the developed model could be applicable out of the study area and broadened to other Mediterranean areas.

Acknowledgements The authors are grateful to Elisa Mellado and Olga López for their assistance in the field work, Carmen Blanco and Juan Carlos Arranz for their advice in laboratory analysis and Gustavo Palacios, Raúl Blanco, Luis Finat, Ovidio Vallejo and Adrián Rossignoli 
of the Junta (regional government) of Castilla y León for providing the information about the plantation year of the stands.

\section{Compliance with ethical standards}

Funding This work was supported by the Ministry of Economy and Competitiveness of the Spanish Government (AGL2011-29701-C02-02 and AGL2014-51964-C2-1-R) and the University of Valladolid and Banco Santander (Predoctoral grant to Teresa BUEIS).

\section{References}

Aertsen W, Kint V, van Orshoven J, Ozkan K, Muys B (2010) Comparison and ranking of different modelling techniques for prediction of site index in Mediterranean mountain forests. Ecol Model 221:1119-1130. doi:10.1016/j.ecolmodel.2010.01.007

Afif-Khouri E, Obregon MAC, Oliveira-Prendes JA, Gorgoso-Varela JJ, Canga-Libano E (2010) Relationship among soil parameters, tree nutrition and site index of Pinus radiata D. Don in Asturias, NW Spain. Forest Syst 19:77-88

Al Omary A (2011) Effects of aspect and slope position on growth and nutritional status of planted Aleppo pine (Pinus halepensis Mill.) in a degraded land semi-arid areas of Jordan. New For 42:285-300. doi:10.1007/s11056-011-9251-2

Alvarez-Alvarez P, Khouri EA, Camara-Obregon A, Castedo-Dorado F, Barrio-Anta M (2011) Effects of foliar nutrients and environmental factors on site productivity in Pinus pinaster Ait. stands in Asturias (NW Spain). Ann For Sci 68:497-509. doi:10.1007/s13595-0110047-5

Assmann E (1970) The principles of forest yield study. Pergamon Press, Oxford, U.K

Bashour II, Sayegh AH (2007) Methods of analysis for soils of arid and semi-arid regions. Food and Agriculture Organization of the United Nations, Rome

Bravo F, Luca M, Mercurio R, Sidari M, Muscolo A (2011) Soil and forest productivity: a case study from Stone pine (Pinus pinea L.) stands in Calabria (southern Italy). iForest 4:25-30. doi:10.3832 /ifor0559-004

Bravo-Oviedo A, Montero G (2005) Site index in relation to edaphic variables in stone pine (Pinus pinea L.) stands in south west Spain. Ann For Sci 62:61-72. doi:10.1051/forest:2004086

Bueis T, Bravo F, Pando V, Turrión M (2016a) Database of site factors in Pinus halepensis Mill. plantations in Spain. doi:10.5281 zzenodo.198522

Bueis T, Bravo F, Pando V, Turrión MB (2016b) Relationship between environmental parameters and Pinus sylvestris L. site index in forest plantations in northern Spain acidic plateau. iForest 9:394-401. doi:10.3832/ifor1600-008

Bundy LG, Bremner JM (1972) Simple titrimetric method for determination of inorganic carbon in soils. Soil Sci Soc Am Pro 36:273-275

Condes S, Garcia-Robredo F (2012) An empirical mixed model to quantify climate influence on the growth of Pinus halepensis Mill. stands in South-Eastern Spain. Forest Ecol Manag 284:59-68. doi:10.1016 /j.foreco.2012.07.030

del Castillo J, Voltas J, Pedro Ferrio J (2015) Carbon isotope discrimination, radial growth, and NDVI share spatiotemporal responses to precipitation in Aleppo pine. Trees-Struct Funct 29:223-233. doi:10.1007/s00468-014-1106-y

De-Martonne E (1926) Une nouvelle fonction climatologique: L'Indece d'aridite. La Meteorologie 2:449-458

DGCN (2002) El Tercer Inventario Forestal Nacional. Ministerio de Medio Ambiente-Dirección General para la Conservación de la Naturaleza, Madrid
Drouineau G (1942) Dosage rapide du calcaire actif de sols. Ann Agron 12

Foote JA, Boutton TW, Scott DA (2015) Soil C and N storage and microbial biomass in US southern pine forests: influence of forest management. Forest Ecol Manag 355:48-57. doi:10.1016/j. foreco.2015.03.036

Gandullo JM, Nicolás A, Sánchez O, Moro J (1972) Ecología de los pinares españoles III. Pinus halepensis Mill. Ministerio de Agricultura. Instituto Nacional de Investigaciones Agrarias, Madrid

Girard F, Vennetier M, Ouarmim S, Caraglio Y, Misson L (2011) Polycyclism, a fundamental tree growth process, decline with recent climate change: the example of Pinus halepensis Mill. in Mediterranean France. Trees-Struct Funct 25:311-322. doi:10.1007/s00468-010-0507-9

Hair JF, Suárez MG, Tatham L, Black C (1999) Análisis multivariante. Prentice Hall, Madrid

Harding RB, Grigal DF, White EH (1985) Site quality evaluation for white spruce plantations using discriminant analysis. Soil Sci Soc Am J 49:229-232

Heyer C (1841) Die Waldertrags-Regelung. Ferber, Giesen

Isermeyer H (1952) Eine einfache Methode sur Bestimmung der Bodenatmung und der Carbonate im Boden. Zeitschrift Pflanzenernährung und Bodenkunde 56:26-38

Jokela EJ, White EH, Berglund JV (1988) Predicting norway spruce growth from soil and topographic properties in New York. Soil Sci Soc Am J 52:809-815

Jolliffe IT (1973) Discarding variables in a principal component analysis II: real data. Appl Stat 22:21-31

Kishchuk BE (2000) Calcareous soils, their properties and potential limitations to conifer growth in southeastern British Columbia and Western Alberta. A Literature Review. Nat. Resour. Can. CfS, North. For. Cent., Edmonton Alberta and Invermere forest district Enhanced forest Management Pilot Project, B. C. Minist. For. Invermere, British Columbia. Inf. Rep. Nor-X-370

Klein T, Hoch G, Yakir D, Korner C (2014) Drought stress, growth and nonstructural carbohydrate dynamics of pine trees in a semi-arid forest. Tree Physiol 34:981-992. doi:10.1093/treephys/tpu071

Kuzyakov Y, Xu XL (2013) Competition between roots and microorganisms for nitrogen: mechanisms and ecological relevance. New Phytol 198:656-669. doi:10.1111/nph.12235

Laamrani A, Valeria O, Bergeron Y, Fenton N, Cheng LZ, Anyomi K (2014) Effects of topography and thickness of organic layer on productivity of black spruce boreal forests of the Canadian Clay Belt region. Forest Ecol Manag 330:144-157. doi:10.1016/j. foreco.2014.07.013

Lang R (1915) Versuch einer exakten Klassifikation der Boden in klimatischer und geologischer Hinsicht. Intern Mitt $\mathrm{f}$ Bodenkunde 5:312-346

Lindsay WL, Norvell WA (1978) Development of a DTPA soil test for zinc, iron, manganese, and copper. Soil Sci Soc Am J 42:421-428

Llorente M, Turrion MB (2010) Microbiological parameters as indicators of soil organic carbon dynamics in relation to different land use management. Eur J For Res 129:73-81. doi:10.1007/s10342-0080249-z

Mahía J, Pérez-Ventura L, Cabaneiro AM, Díaz-Raviña M (2006) Soil microbial biomass under pine forests in the northwestern Spain: influence of stand age, site index and parent material. Inv AgrarSist Rec F 15:152-159

MAPA (1993) Métodos oficiales de análisis. Tomo III. Ministerio de Agricultura, Pesca y Alimentación. Gobierno de España, Madrid

Maseyk K, Hemming D, Angert A, Leavitt SW, Yakir D (2011) Increase in water-use efficiency and underlying processes in pine forests across a precipitation gradient in the dry Mediterranean region over the past 30 years. Oecologia 167:573-585. doi:10.1007/s00442011-2010-4 
Montero G, Cañellas I, Ruiz-Peinado R (2001) Growth and yield models for Pinus halepensis Mill. Inv Agrar-Sist Rec F 10:179-201

Murphy J, Riley JP (1962) A modified single solution method for the determination of phosphorus in natural waters. Anal Chim Acta 27: 31-36. doi:10.1016/s0003-2670(00)88444-5

Muscolo A, Panuccio MR, Mallamaci C, Sidari M (2014) Biological indicators to assess short-term soil quality changes in forest ecosystems. Ecol Indic 45:416-423. doi:10.1016/j.ecolind.2014.04.047

Ninyerola M, Pons i Fernández X, Roure JM (2005) Atlas climático digital de la Península Ibérica: metodología y aplicaciones en bioclimatología y geobotánica. Universidad Autónoma de Barcelona, Bellaterra, Barcelona, Spain

Olarieta JR, Uson A, Rodriguez R, Rosa M, Blanco R, Antunez M (2000) Land requirements for Pinus halepensis Mill. growth in a plantation in Huesca, Spain. Soil Use Manage 16:88-92. doi:10.1111/j.14752743.2000.tb00180.x

Ortega A, Montero G (1988) Evaluación de la calidad de las estaciones forestales. Revisión bibliográfica Ecología 2:155-184

Pasho E, Julio Camarero J, de Luis M, Vicente-Serrano SM (2011) Impacts of drought at different time scales on forest growth across a wide climatic gradient in north-eastern Spain. Agric For Meteorol 151:1800-1811. doi:10.1016/j.agrformet.2011.07.018

Pietrzykowski M, Socha J, van Doorn NS (2015) Scots pine (Pinus sylvestris $\mathrm{L}$.) site index in relation to physico-chemical and biological properties in reclaimed mine soils. New For 46:247-266. doi:10.1007/s11056-014-9459-Z

Rathgeber CBK, Misson L, Nicault A, Guiot J (2005) Bioclimatic model of tree radial growth: application to the French Mediterranean Aleppo pine forests. Trees-Struct Funct 19:162-176. doi:10.1007 /s00468-004-0378-z

Recous S, Robin D, Darwis D, Mary B (1995) Soil inorganic N availability: effect on maize residue decomposition. Soil Biol Biochem 27:1529-1538. doi:10.1016/0038-0717(95)00096-W

Richards LAE (1954) Diagnosis and improvement of saline and alkali soils vol US Department of Agriculture Handbook 60. US Salinity Lab, California, USA

Río M, Rodriguez-Alonso J, Bravo-Oviedo A, Ruiz-Peinado R, Canellas I, Gutierrez E (2014) Aleppo pine vulnerability to climate stress is independent of site productivity of forest stands in southeastern Spain. Trees-Struct Funct 28:1209-1224. doi:10.1007/s00468014-1031-0

Romanya J, Vallejo VR (2004) Productivity of Pinus radiata plantations in Spain in response to climate and soil. Forest Ecol Manag 195: 177-189. doi:10.1016/j.foreco.2004.02.045

Sabate S, Gracia CA, Sanchez A (2002) Likely effects of climate change on growth of Quercus ilex, Pinus halepensis, Pinus pinaster, Pinus sylvestris and Fagus sylvatica forests in the Mediterranean region. Forest Ecol Manag 162:23-37. doi:10.1016/s0378-1127(02)000488

Sanchez-Rodriguez F, Rodriguez-Soalleiro R, Espanol E, Lopez CA, Merino A (2002) Influence of edaphic factors and tree nutritive status on the productivity of Pinus radiata D. Don plantations in northwestern Spain. Forest Ecol Manag 171:181-189. doi:10.1016 /s0378-1127(02)00471-1

Schloter M, Dilly O, Munch JC (2003) Indicators for evaluating soil quality. Agric Ecosyst Environ 98:255-262. doi:10.1016/S01678809(03)00085-9

Schollenberger CJ, Simon RH (1945) Determination of exchange capacity and exchangeable bases in soil-ammonium acetate method. Soil Sci 59:13-24. doi:10.1097/00010694-194501000-00004

Skovsgaard JP, Vanclay JK (2008) Forest site productivity: a review of the evolution of dendrometric concepts for even-aged stands. Forestry 81:13-31. doi:10.1093/forestry/cpm041

Song M, Xu X, Hu Q, Tian Y, Ouyang H, Zhou C (2007) Interactions of plant species mediated plant competition for inorganic nitrogen with soil microorganisms in an alpine meadow. Plant Soil 297:127-137. doi:10.1007/s11104-007-9326-1

Staddon WJ, Duchesne LC, Trevors JT (1999) The role of microbial indicators of soil quality in ecological forest management. Forest Chron 75:81-86. doi:10.5558/tfc75081-1

Statgraphics (2014) Statgraphics Centurion XVII User Manual StatPoint Technologies Inc, USA

Thornthwaite C (1949) A rational approach to the classification of climate. Geogr Rev 38:55-94

Thornthwaite CW, Mather JR (1955) The water balance vol 8. Laboratory of Climatology, Centerton, NJ, USA

Toromani E, Pasho E, Alla AQ, Mine V, Collaku N (2015) Radial growth responses of Pinus halepensis Mill. and Pinus pinea L. forests to climate variability in western Albania. Geochronometria 42:91-99. doi:10.1515/geochr-2015-0012

Turrión MB, Gallardo JF, González MI (1997) Nutrient availability in forest soils as measured with anion exchange membranes. Geomicrobiol J 14:51-64. doi:10.1080/01490459709378033

Vance ED, Brookes PC, Jenkinson DS (1987) An extraction method for measuring soil microbial biomass-C. Soil Biol Biochem 19:703707. doi:10.1016/0038-0717(87)90052-6

Walkley A, Black IA (1934) An examination of the Degtjareff method for determining soil organic matter, and a proposed modification of the chromic acid titration method. Soil Sci 37:29-38. doi:10.1097 /00010694-193401000-00003 